ERnst, W. (1968). Der Einfluss der Phosphatversorgung sowie die Wirkung von ionogenem und chelatisiertem Zink auf die Zink-und Phosphataufnahme einiger Schwermetallpflanzen. Physiologia Pl., 21, pp. 323-33.

GADGIL R. L. (1969). Tolerance of heavy metals and the reclamation of industrial waste. J. Appl. Ecol., 6, pp. 247-59.

Gorham, E. \& Gordon, A. G. (1960a). Some effects of smelter pollution north-east of Falconbridge, Ontario. Can. J. Bot., 38, pp. 307-12.

Gorham, E. Gordon, A. G. (1960b). The influence of smelter fumes upon the chemical composition of lake waters near Sudbury, Ontario, and upon the surrounding vegetation. Can. J. Bot., 38, pp. 477-87.

Gregory, R. P. G. \& Bradshaw, A. D. (1965). Heavymetal tolerance in populations of Agrostis tenuis Sibth. and other grasses. New Phytol., 64, pp. 131-43.

Hutchinson, E. G. (1945). Aluminium in soils, plants and animals. Soil Science, 60, pp. $29-40$.

Hutchinson, T. C. (1973). Comparative studies of the phytotoxicity of heavy metals to phytoplankton and their synergistic interactions. Symposium on Water Pollution Research in Canada, 8, pp. 68-90.

Hutchinson, T. C. \& Whitby, L. M. (1974). Heavy-metal pollution in the Sudbury mining and smelting region of Canada, I. Soil and vegetation contamination by nickel, copper, and other metals. Environmental Conservation, 1(2), pp. 123-32, map.

JACKson, M. L. (1958). Soil Chemical Analysis. PrenticeHall, New York: xiv + 498 pp., illustr.

Jowetr, D. (1958). Populations of Agrostis spp. tolerant of heavy metals. Nature (London), 182, pp. 816-7.

JowETT, D. (1964). Population studies on lead-tolerant Agrostis tenuis. Evolution, 18, p. 70.

Kubota, J. \& Allaway, W. H. (1972). Geographic distribution of trace-element problems. Pp. 525-54 in Micronutrients in Agriculture (Ed. J. J. Mortvedt, P. M. Giordano \& W. L. Lindsay). Soil Science Society of America, Madison, Wisconsin: xix + 666 pp., illustr.

LINZON, S. N. (1972). Effects of sulphur oxides on vegetation. Foresty Chronicle, 48, pp. 182-6.
LuCAs, R. E. \& Davis, J. F. (1961). Relationships between pH values of organic soils and availabilities of 12 plant nutrients. Soil Science, 92, pp. 177-82.

MCKeE, J. E. \& Wolf, H. W. (1963). Water Quality Criteria (2nd edn). California State Water Pollution Control Board, Publication No. 3-A, xiv + 548 pp., illustr.

Munshower, Frank F. (1972). Cadmium Compartmentation and Cycling in a Grassland Ecosystem in the Deer Lodge Valley, Montana. Ph. D. thesis, University of Montana, Missoula: 103 pp., (typescript).

Reuther, W., Smith, P. F. \& Specht, A. W. (1952). Accumulation of the major bases and heavy metals in Florida citrus soils in relation to phosphate fertilization. Soil Science, 73, pp. 374-81.

RoRISON, I. H. (1960). The calcicole-calcifuge problem. II. The effects of mineral nutrition on seedling growth in solution culture: $J$. Ecol., 48, pp. 679-88.

Schmitt, N., Devlin, E. L., Larsen, A. A., McCausland, E. D. \& Saville, J. M. (1971). Lead poisoning in horses. Arch. Environ. Health, 23, pp. 185-95.

SPARLING, J. H. (1967). The occurrence of Schoenus nigricans L. in blanket bogs. I. Environmental conditions affecting the growth of $S$. nigricans in blanket bogs. J. Ecol., 55, pp. 1-14.

Spence, D., H. N. (1957). Studies on the vegetation of Shetland. I. The serpentine debris vegetation in Unst. J. Ecol., 45, pp. 917-45.

Thomas, M. D. (1965). The effects of air pollution on plants and animals. Pp. 11-33 in Ecology and the Industrial Society (Ed. G. T. Goodman, R. W. Edwards \& J. M. Lambert). 5th Symp. Brit. Ecol. Soc., Blackwell, Oxford: viii +395 pp., illustr.

WILD, H. (1970). Geobotanical anomalies in Rhodesia. 3. The vegetation of nickel-bearing soils. Kirkia, 1, Supplement, pp. 1-62.

Wilkins, D. A. (1957). A technique for the measurement of lead tolerance in plants. Nature (London), 180, pp. 37-8.

Wilkins, D. A. (1960). The measurement of genetical analysis of lead tolerance in Festuca ovina. Rep. Scott. Pl. Breed. Stn, pp. 85-98.

\title{
International Seminar on Environmental Management for Industrialists
}

During 27-31 January 1975 the Centre d'Études Industrielles (CEI), Geneva, will be holding an 'International Environmental Management Seminar', with the object of bringing together decision-makers and environmental advisers from both the public and private sectors of government and industry, so that they can discover and discuss how best to deal with the problems posed by industry's impact on the environment. The participants will include project managers, corporate planners, and environmental coordinators, as well as national and international civil servants and managers of public enterprises, from a large number of different countries.

The seminar will consist of formal lectures which will deal with the methodologies of environmental impact assessment, conflict resolution, and strategy development, plus extensive working in small groups where participants can apply these techniques to specific cases of the impact of an industrial project on the environment. Working in such groups and circumstances enables participants to draw on their diverse industrial and national backgrounds in solving the various problems posed, thus broadening their perspective of these problems and seeing the opportunity for developing new solutions.

The seminar is being coordinated by the undersigned, a British chemical engineer, who is the Faculty Member in Environmental Management at the CEI, in conjunction with Dr William H. Matthews of the Massachusetts Institute of Technology. Maurice Strong, Executive Director of the United Nations Environment Programme and Chairman of the Foundation Board of CEI, will give the Theme Speech, and other eminent personalities will be involved.

Michael G. Royston, Programme Coordinator International Environmental Management Seminar Centre d'Études Industrielles

4 chemin de Conches

1211 Conches, Geneva, Switzerland. 